DOI:

UDC 621.333:519.87

O.I. Sheremet, Doctor of Tech. Sc., Associate Professor, sheremet-oleksii@ukr.net

N.V. Klimchenkova, Candidate of Tech. Sc., Associate Professor, klimchenkova.nat34@gmail.com Donbass State Engineering Academy, Kramatorsk

O.V.Sadovoi, Doctor of Tech. Sc., Professor, sadovoyav@ukr.net

Yu.V. Sokhina, Candidate of Tech. Sc., Associate Professor, elm@dstu.dp.ua

Dniprovsk State Technical University, Kamyanske

\title{
DEVELOPMENT OF THE MATHEMATICAL MODEL FOR CALCULATION OF UNSTABLE TEMPERATURE-MECHANICAL STRESSES IN THE TRACTION MOTOR
}

The article deals with the issues of calculation of unsteady temperature-mechanical stresses in the collectors of traction electric motors for technological and operational modes, which contributes to increasing the reliability and competitiveness of domestic electric locomotives.

The results of the theoretical study of the distribution of the temperature-mechanical forces in the traction motor's collectors are carried out for the most dangerous heavy transient modes, which include: dynamic formation of the collector at high temperature at an increased frequency of rotation; test of the engine produced at an increased frequency of rotation; start of the engine under load in nominal mode or at maximum load, limited class of insulation resistance of the collector.

The most research results are obtained for the process of manufacturing collectors of traction electric motors of main electric locomotives, but they can also be used for the technology of manufacturing electric machines for direct current with other operational purposes.

Key words: collector; traction electric motor; unsteady parameters; temperature-mechanical stresses

У статті розглянуті питання розрахунку несталих температурно-механічних напружень у колекторах тягових електродвигунів для технологічних та експлуатачійних режимів, що сприяють підвищенню надійності та конкурентоспроможності вітчизняних електровозів.

Результати теоретичного дослідження розподілу температурно-механічних зусиль у колекторах тягових електродвигунів проведені для найбільш небезпечних важких перехідних режимів, до яких відносять: динамічне формування колектору при високій температурі на підвищеній частоті обертання; випробування виготовленого двигуна при підвищеній частоті обертання; пуск двигуна під навантаженням у номінальному режимі або при максимальному навантаженні, обмеженому класі нагрівостійкості ізоляції колектору.

Більшість результатів досліджень отримано для процесу виготовлення колекторів тягових електродвигунів магістральних електровозів, але вони можуть бути також використані до технології виготовлення електричних машин постійного струму з іншим експлуатаиійним призначенням.

Ключові слова: колектор; тяговий електродвигун; несталі параметри; температурномеханічні напруження

\section{Formulation of the problem}

The comprehensive program of updating of the railway rolling stock of Ukraine for the years 2008 - 2025, which was put into effect by the order of the Ministry of Transport and Communications No. 12559 of October 14, 2008, is aimed at the production and updating of own powerful electric locomotives and requires reliable traction motors.

According to [1] 50\% of all failures of traction motors (TM) accounted for the main electric collector where significant influence unstable temperature and mechanical forces both in technology and in operating conditions. The method of calculation and identification unsteady temperature fields and temperature and mechanical stress in the elements of modern collectors TM acquired at present of particular relevance.

Collectors of TMs are operating under different fluctuations of electrical and mechanical loads in ambient temperature changes from $-60{ }^{\circ} \mathrm{C}$ to $+40{ }^{\circ} \mathrm{C}$. Initial mechanical stresses caused by tighten- 
ing the collector with bolts or other fasteners are created during collection. Temperature mechanical stresses occur when carrying out the operations of a technological process for the production of TMs, during tests, in operating modes and due to the difference in temperature and coefficients of temperature expansion of the elements, the presence of structural links between the elements, which prevent the free change of their sizes. Temperature mechanical stresses are superimposed on mechanical stresses from the tightening forces and centrifugal forces that occur when the collector is rotated, significantly reducing the initial safety margin of the structure.

It is difficult to experimentally determine the effect of temperature and mechanical stress on the operation of TM over a period of time. Therefore, it is advisable to develop a mathematical model for the calculation of constant temperature-mechanical stresses in the collector of the traction motor.

\section{Analysis of recent research and publications}

According to available data [1-4], in severe transient modes, the temperature stresses can increase by $20-30 \%$ the magnitude of mechanical stresses that occurred in the collector elements at the beginning of the mode. This significantly affects the reliability of the collector and traction motors installed on the main electric locomotives.

The factors that characterize the thermal and mechanical strength of the collectors include: the rated power of the engine, relative to the area of the working surface of the collector; specific losses of ventilating air; specific power losses on the collector work surface; power losses per unit mass of copper of the collector circular arch; current density in brushes; maximum circumferential velocity of the collector work surface; excess temperature of the structural elements above the temperature of the ventilating air; the coefficient of increase of the primary efforts in the elements of the collector due to the change in its temperature state.

The analysis of the above factors for TM in recent years showed that during this period of time the intensity of operation of main electric locomotives has increased by $2-3$ times $[1,2,4]$. The above points out, that the issues of research and calculation of temperatures and temperaturemechanical stresses in the collectors of modern TMs have received important theoretical and practical importance in terms of the operational reliability of the collectors.

Analyzing existing methods of calculating temperatures and temperature and mechanical stress in the collectors of electrical machines include the following features:

1. In most scientific works, only constant temperature-mechanical stresses are calculated or the coefficient of increase of mechanical stresses due to temperature influence is recommended.

2. In the known scientific works, the calculation of average temperature exceedances of copper or copper and collector steel in steady state is calculated, for transient modes, the excess copper temperature is expressed for heating a homogeneous body, or it is recommended to use thermal circuits of substitution; there is no ambiguity in the approach to determining the area of heat transfer surfaces and the magnitudes of heat transfer coefficients.

3. Calculation of only constant temperatures and temperature-mechanical stresses in the elements of the collector cannot fully ensure the operational reliability of the TM collectors, the elements of which are influenced by the considerable temperature efforts in the transient modes of production, testing and operation, when the greatest differences between copper and steel temperatures occur.

\section{Formulation of research objectives}

The purpose of the work is to develop a methodology for calculating and identifying of temperature fields and temperature-mechanical stresses in TM collectors under non-constant modes.

According to the purpose in the work the following tasks are set and solved:

- sequence of calculation of temperature mechanical stresses and temperatures under nonconstant modes is proposed;

- theoretical studies of the distribution and change of temperatures and temperaturemechanical stresses in the elements of Tb collectors in non-constant modes have been carried out;

- a system for identification of temperature-mechanical stresses was developed and recommendations for their reduction were given.

The object of the study - the processes of occurrence of temperature-mechanical stresses.

The subject of the study - the identification and analysis of the distribution of temperaturemechanical forces and their influence on the state of the TM collector elements design. 


\section{Presentation of basic material}

The collector is a complex system of a large number of structurally related solids, for each of which the heat transfer processes are described by differential thermal conductivity equations $[3,4]$.

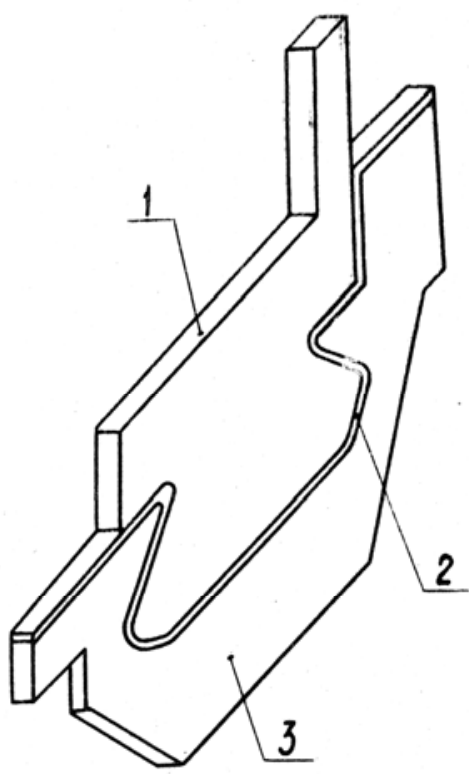

Fig. 1. Settlement sector of collector with insulating cuffs: 1 - collector plate; 2 - case insulation; 3 - case Thus, the thermal processes in the collector will be described by a large number of differential thermal conductivity equations and equations describing the boundary and initial conditions of each of the bodies. However, the geometric symmetry of the design can greatly simplify the thermal calculation of the collector and increase its accuracy. For this purpose, the design sector is distinguished from the structure, which includes the volume of the collector, which belongs to the collector division $[2,3]$. The volume of the sector includes three bodies with the same thermophysical properties within each of them: the collector plate, part of the body insulation, part of the case. This simplifies the calculation task.

Fig. 1 simplifies the calculation sector of the collector with insulating cuffs. The basic assumption adopted by the thermal calculation selected sector is the lack of heat in the direction of neighboring sectors, as all sectors are experiencing the same collector thermal influences. Loss of power, leading to the estimated body heat sector are determined by dividing the total power losses on the working surface of the collector $\left(\Delta P_{m p}+\Delta P_{e}\right)$ on the number of collector plates. Since

power losses are concentrated in a very thin layer near the working surface (in the area of alternating brush - collector), they can be considered as surface heat sources and are included in the equation for the boundary conditions of the collector plate $[2,3]$.

Experimental studies have found that it is possible to consider a one-dimensional temperature field and to determine only the change in temperature along the radius of the collector. The effect of the armature winding on the temperature distribution of the collector can be accounted by a corresponding increase in the total power loss on the collector. Fig. 2 shows a calculation scheme of thermal processes in the collector sector, based on which a mathematical model of thermal processes can be represented as a system of three differential equations of thermal conductivity in partial derivatives with boundary and initial conditions.

For the collector plate the differential heat equation is as follows:

$$
\lambda_{1} \frac{\partial^{2} \Theta_{1}(x, t)}{\partial x^{2}}=c_{1} \cdot \rho_{1} \cdot \frac{\partial \Theta_{1}(x, t)}{\partial t}, 0 \leq x \leq \delta_{1}, t>0,
$$

where $\lambda_{1}$ - thermal conductivity of the material of the plate, $\mathrm{W} /\left(\mathrm{m} \cdot{ }^{\circ} \mathrm{C}\right) ; c_{1}$ - specific heat of the material $\mathrm{W} \cdot \mathrm{s} /\left(\mathrm{kg} \cdot{ }^{\circ} \mathrm{C}\right) ; \rho_{1}$ - density of material, $\mathrm{kg} / \mathrm{m}^{3} ; \Theta_{1}\left(x_{1}, t\right)$ - the required function of distribution of excess temperatures by the height of the plate for any time, ${ }^{\circ} \mathrm{C} ; \delta_{1}$ - height of the plate (radial size), $\mathrm{m}$.

For the case insulation

$$
\lambda_{2} \frac{\partial^{2} \Theta_{2}(x, t)}{\partial x^{2}}=c_{2} \cdot \rho_{2} \cdot \frac{\partial \Theta_{2}(x, t)}{\partial t}, \delta_{1} \leq x \leq \delta_{1}+\delta_{2}, t>0,
$$

where $\lambda_{2}, c_{2}, \rho_{2}$ - accordingly, the coefficient of thermal conductivity, specific heat and density of the material of the case insulation; $\Theta_{2}(x, t)$ - the required function of distribution of excess temperatures on the thickness of the case insulation layer, ${ }^{\circ} \mathrm{C} ; \delta_{2}$ - thickness of the layer (radial size) of the case insulation, $\mathrm{m}$. 


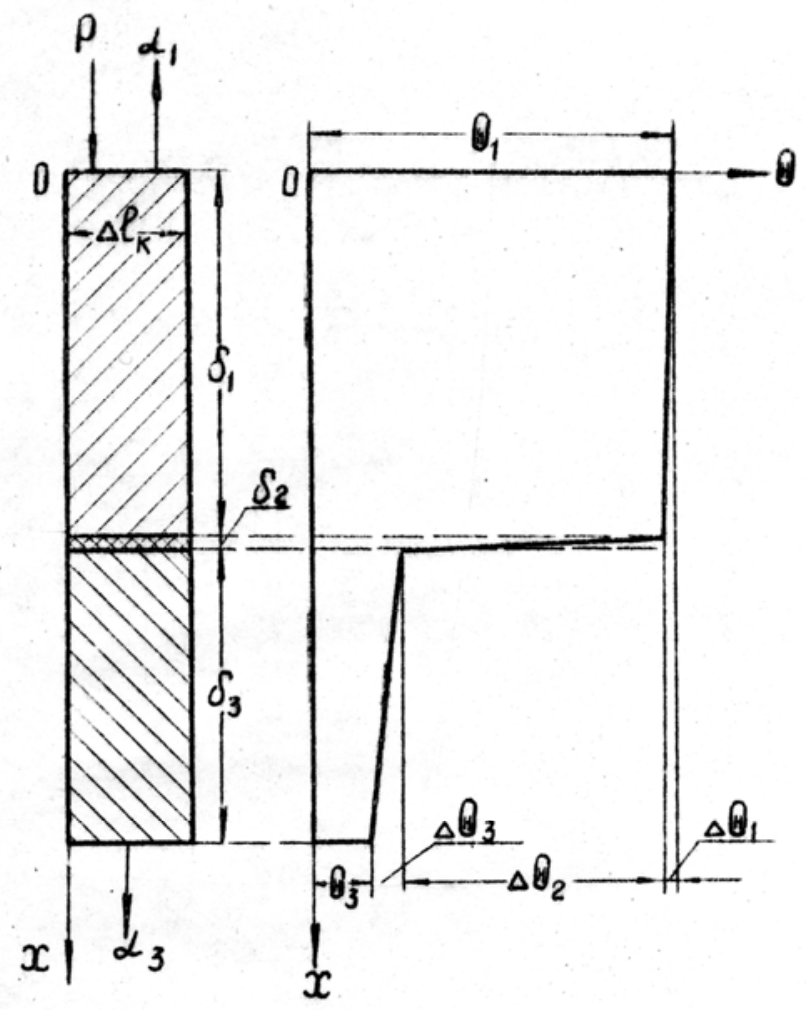

Fig. 2. Calculation scheme of thermal processes in the collector sector and relative change in temperature over the radius

For the case

$$
\lambda_{3} \frac{\partial^{2} \Theta_{3}(x, t)}{\partial x^{2}}=c_{3} \cdot \rho_{3} \cdot \frac{\partial \Theta_{3}(x, t)}{\partial t}, \delta_{1}+\delta_{2} \leq x \leq \delta_{1}+\delta_{2}+\delta_{3}, t>0,
$$

where $\lambda_{3}, c_{3}, \rho_{3}$ - accordingly, the coefficient of thermal conductivity, specific heat and density of the case material; $\Theta_{3}(x, t)$ - the required function of temperature distribution over radial size of the case, ${ }^{\circ} \mathrm{C} ; \delta_{3}$ - the radial size of the collector body.

The boundary conditions for the contact layer and the heat transfer layer are as follows:

$$
\begin{gathered}
P-\alpha_{1} \cdot\left(\partial \Theta_{1}(x, t)-\Theta_{0}\right)=-\lambda \frac{\partial \Theta_{1}(x, t)}{\partial t}, x=0 ; \\
\lambda_{1} \frac{\partial \Theta_{1}(x, t)}{\partial x}=\lambda_{2} \frac{\partial \Theta_{2}(x, t)}{\partial x}, \Theta_{1}(x, t)=\Theta_{2}(x, t), x=\delta_{1} ; \\
\lambda_{2} \frac{\partial \Theta_{2}(x, t)}{\partial x}=\lambda_{3} \frac{\partial \Theta_{3}(x, t)}{\partial x}, \Theta_{2}(x, t)=\Theta_{3}(x, t), x=\delta_{1}+\delta_{2} ; \\
-\lambda_{3} \frac{\partial \Theta_{3}(x, t)}{\partial x}=\alpha_{3}\left(\Theta_{3}(x, t)-\Theta_{0}\right), x=\delta_{1}+\delta_{2}+\delta_{3},
\end{gathered}
$$

where $P$ - specific power losses on the working surface of the collector plate, $\mathrm{W} / \mathrm{m}^{2} ; \alpha_{1}$ - plate heat transfer coefficient, $\mathrm{W} /\left(\mathrm{m}^{2} \cdot{ }^{\circ} \mathrm{C}\right) ; \alpha_{3}$ - coefficient of heat transfer surface of the body, $\mathrm{W} /\left(\mathrm{m}^{2} \cdot{ }^{\circ} \mathrm{C}\right) ; \Theta_{0}$ - exceeding the temperature of the cooling air collector, ${ }^{\circ} \mathrm{C}$.

Initial conditions for the bodies of the settlement sector:

$$
\Theta_{1}(x, t)=\Theta_{2}(x, t)=\Theta_{3}(x, t)=\Theta_{\text {init }}, t=0,
$$

where $\Theta_{\text {init }}$ - the initial excess of the temperature of the sector bodies, ${ }^{\circ} \mathrm{C}$. 
Due to thermal parameters of materials, mathematical model of thermal processes can be simplified. Since the coefficients of thermal conductivity of the collector copper and steel of the case are more than 100 times greater than the coefficient of thermal conductivity of the body insulation (cuffed micanite), their value can be considered infinitely large $\left(\lambda_{1}=\lambda_{3}=\infty\right)$. Physically, this means that the temperature of the plate and the case is almost unchanged in the radius of the collector. The heat capacity of the case insulation layer is assumed to be zero compared to the heat capacity of the plate and the body, since the thickness of this layer is $20-30$ times smaller than the height of the plate $\left(\delta_{1}\right)$ and the radial size of the case $\left(\delta_{3}\right)$. Accepted assumptions lead to a simplification of the system of equations. The influence of the heat capacity of the plate and the case on the change in the temperature field in a non-constant thermal process is taken into account by introducing these quantities into boundary conditions for the layer of body insulation. Accept $\Theta_{0}=0$ that practically takes place.

Then the desired function of the distribution of excess temperature over the thickness of the insulation layer:

$$
\Theta_{2}(x, t)=\frac{1}{\lambda_{2}}\left(-P+\alpha_{1}\left(C_{1} e^{k_{1} t}+C_{2} e^{k_{2} t}-\frac{a_{0}}{a_{1}}\right)-C_{1} \rho_{1} \delta_{1}\left(C_{1} k_{1} e^{k_{1} t}+C_{2} k_{2} e^{k_{2} t}\right)\right) \cdot x+C_{1} e^{k_{1} t}+C_{2} e^{k_{2} t}-\frac{a_{0}}{a_{1}} .
$$

The resulting expression (9) contains the parameters of the design and the thermal process, allows to calculate the distribution of temperature changes in layer thickness of hull insulation $\left(0 \leq x \leq \delta_{2}\right)$ for any point in time unsteady thermal process. Using the obtained expression, it is possible to determine the average excess temperature of copper of the circular arch of the collector at $x=0$, since this value of abscissa corresponds to the limit of contact of the plate with the case insulation. The average excess temperature of the collector case is obtained from (9) at $x=\delta_{2}$, since this value of the abscissa corresponds to the limit of contact of the case with the case insulation. Thus, for any moment of time of a non-constant thermal process in accordance with (9), the excess temperature of the elements of the collector structure is determined. The steady-state temperatures of the collector elements, as the final state of the non-constant temperature field at the given mode parameters, can be obtained from (9) at $t=\infty$. The presence of temperature-time dependencies for the elements of the collector allows proceeding to the calculation of non-constant temperature mechanical stresses in the structural elements.

The mathematical model of the collector thermal processes, given in the form of the system of equations (1) - (8), can be interpreted by means of thermal substitution schemes. The main provisions of the thermal substitution circuit method are set out in the known literature $[1,2,4]$ and are used in thermal calculations of electric machines. The essence of the thermal substitution circuit is that heat from the concentrated sources of thermal energy through the concentrated thermal supports is diverted to the cooling electric machine of the air. The sampling of the collector temperature field and the transition to temperature distributions of the same magnitude within some body volumes allow the partial differential equations to be replaced by partial first-order differential equations for non-constant modes and a system of linear algebraic equations for steady-state modes.

The assumptions used in developing the thermal equivalent circuit. Development of thermal equivalent circuit collector held under such conditions and assumptions $[1,2,4]$ :

1. The settlement sector of the collector is divided into volumes within which the thermophysical properties of the materials are the same, and the distribution of parameters in these volumes is replaced by concentrated supports, while maintaining thermal bonds between them.

2. To account for the effect of the armature on the temperature distribution, the collector armature is allocated in the collector, which includes the volume belonging to one collector division and has a thermal connection to the collector by the copper winding of the armature.

3. Power losses on the collector work surface and in the armature are represented as concentrated sources of thermal energy. It is possible to take into account the effect of the armature on the temperature distribution in the collector by correspondingly increasing the power loss on the collector work surface. There is no heat transfer between the selected settlement sector and the rest of the col- 
lector. The linear law of change of excess of cooling air temperature along the length of electric machine is adopted.

4. Thermal resistances of heat transfer from the collector surfaces and resistances during heat transfer by thermal conductivity are determined according to the expression given in $[1-4]$. When calculating the unsteady temperature field of a collector, the initial temperature distribution by design element is determined, and the concentrated heat capacities of the volumes into which the calculated sector is divided are taken into account.

The temperature-time dependencies of the collector elements when using thermal substitution schemes are in good agreement with the calculated analytical method, which allows the use of the collector substitution scheme for further calculations.

The purpose of mechanical calculations for collectors is to determine the maximum stresses in structural elements at all possible temperature conditions, which allows identifying the weakest elements of the designed collector and creating a reliable structure. Issues of calculation of temperature mechanical stresses arising in the elements of the collector design of electric machines under steadystate modes, have been most fully reflected in $[5,6]$.

The elements of the collector structure can be acted upon at the same time by three types of forces: forces caused by tightening the collector with bolts or other fasteners that occur during the production of the collector; temperature mechanical forces caused by the change in the collector temperature field arising during production, during testing, during operation; centrifugal forces that occur when the collector rotates. Temperature mechanical forces arising due to the temperature difference between the collector and temperature coefficient of linear expansion of copper collector plates $\left(\alpha_{C u}\right)$ and steel construction fasteners $\left(\alpha_{F e}\right)$. The difference in copper and steel temperatures of the collector depends on the design, mode parameters, ventilation conditions and is determined by the thermal calculation of the collector. The copper coefficient is 1.54 times higher than the steel of the collector. As the steel mounting elements of the collector limit the axial deformations of the collector plate set, the temperature mechanical stresses are determined by the difference of the thermal deformations of the copper and steel in the axial direction and the elasticity of the collector elements. Thermal deformations of structural elements occur both due to the direct elongation of a set of copper plates and clamping bolts, and by increasing the diameter of the "swallow tail" of the circular arch of the collector and the pressure cones of the case components.

When the collector structure is heated in the process of static or dynamic collector formation, the axial size of the circular arch increases between the middle of the supporting surfaces of the "swallow tail" of the arch and the expansion cones and clamping bolts are expanded. Thus, there is an increase in the length of the elements of the collector, which depends on the excess temperature and can be determined as follows:

$$
\begin{aligned}
& \Delta \ell_{C u}=\left(\Theta_{\text {fin }}-\Theta_{\text {init }}\right)_{C u} \cdot \alpha_{C u} \cdot\left(\ell_{C u}+2 R_{N} / \operatorname{tg}\left(\alpha_{k}\right)\right) . \\
& \Delta \ell_{F e}=\left(\Theta_{\text {fin }}-\Theta_{\text {init }}\right)_{F e} \cdot \alpha_{F e} \cdot\left(\ell_{F e}+2 R_{N} / \operatorname{tg}\left(\alpha_{k}\right)\right) .
\end{aligned}
$$

As the freedom of thermal deformation of the collector circular arch is limited by the fasteners, an additional axial force $T_{\Theta}$ occurs when the collector is heated, which stretches the reinforcing elements and compresses the circular collector arch through the cuffs.

This effort is determined by the condition of the deformation of the arch and the fasteners of the heated collector, taking into account the pliability of its connections. The additional axial force resulting from the change in excess of the temperature of the copper circular arch at $\left(\Theta_{f i n}-\Theta_{i n i t}\right)_{C u}$, and the mounting elements of the collector at $\left(\Theta_{f i n}-\Theta_{\text {init }}\right)_{F e}$, will be determined from (11):

$$
T_{\Theta}=\Delta \ell_{C u}-\Delta \ell_{F e} /\left(\lambda_{p}+\lambda_{\kappa}+\lambda_{\delta}+\lambda_{M}\right) \text {. }
$$

Then the increase of initial forces and mechanical stresses in the elements of the collector structure, caused by the occurrence of additional axial force when changing the temperature state of the structure, is estimated by the following temperature coefficient:

$$
K_{\Theta}=T_{\text {fin }} / T_{\text {init }}=1+T_{\Theta} / T_{\text {init }} .
$$


The resulting mechanical stresses in the elements of the fixed collector at the new temperature state of the structure will be equal to the sum of the initial and temperature mechanical stresses, which are easily distinguished by subtracting the primary stresses from the resulting stresses. The increase in the primary forces and mechanical stresses in the elements of the structure under the influence of centrifugal forces during the rotation of the collector is estimated by the speed coefficient

$$
K_{c}=1+C_{a x} \cdot \lambda_{p} /\left(T \cdot \sum \lambda\right),
$$

where $C_{a x}$ - axial component of centrifugal force circular collector arch, $\mathrm{N} ; T$ - collector tightening axial force, $\mathrm{N} ; \sum \lambda$ - total compliance structural elements of the collector, $\mathrm{m} / \mathrm{N}$.

The simultaneous influence of centrifugal and temperature mechanical forces on the value of primary mechanical stresses in the elements of the collector structure is estimated by multiplying the coefficients $K_{\Theta} \cdot K_{c}$.

Methods of calculations. Based on this, it can be presented the following sequence of calculation in non-constant modes:

1. According to the method [4] determined the initial stresses in the elements of the design of real collector (elements at the same temperature $+20^{\circ} \mathrm{C}$ ), due to tightening manifold bolts compliance elements. For temperature-time dependences of structural elements of the collector thermal calculation is made one of the proposed methods for a given mode settings. The entire time period of the nonconstant thermal process will be divided by the finite number of intervals and the excess temperature of the collector elements at the beginning $\left(\Theta_{\text {init }}\right)$ and end $\left(\Theta_{\text {fin }}\right)$ of each of the time intervals is fixed, the final excess of the element temperature for the previous period of time is the initial one for the next one. Changes are made to the excess temperature of copper circular arch $\left(\Theta_{f i n}-\Theta_{i n i t}\right)_{C u}$ and steel fasteners $\left(\Theta_{f i n}-\Theta_{i n i t}\right)_{F e}$ for the first time in expressions (10) and (11), there is a difference of thermal deformations of these elements $\left(\Delta \ell_{C u}-\Delta \ell_{F e}\right)$, the expressions (12) and (13) are the temperature force $\left(T_{\Theta}\right)$ and the temperature coefficient $\left(K_{\Theta}\right)$ for the first time interval.

2. Multiplication of the primary mechanical stresses in the elements of the fixed collector by the temperature coefficient gives the resulting mechanical stresses in these elements until the end of the first period of time at the new temperature state. The mechanical stresses in the structural elements until the end of the next period of time at the new temperature state are in the same way as for the previous one. The process of calculating mechanical stresses is repeated until the thermal process is established.

3. Taking into account the influence of centrifugal forces during the rotation of the collector on the magnitude of mechanical stresses in the elements of the fixed collector is carried out by multiplying the resulting mechanical stresses for any period of time of a non-constant thermal process by the velocity coefficient $\left(K_{c}\right)$. As a result of the calculation, the dependence is obtained, which characterizes the change of temperature mechanical stresses in the elements of the collector structure during a non-constant thermal process.

The study of temperature distribution and temperature mechanical stresses in the TM collector of the locomotive DE-1 was carried out to one of the most difficult non-permanent modes - the dynamic formation of the collector at a temperature of $+160{ }^{\circ} \mathrm{C}$ and high rotation speed. The initial mechanical stresses in the elements of the fixed collector at a temperature of $+20^{\circ} \mathrm{C}$ are: in the cuff about 46.1 MPa; in the "swallow tail" of the collector plate, the voltage was $143.2 \mathrm{MPa}$; in the tightening bolt - 332.9 MPa; specific pressure between the collector plates - 44.65 MPa; axial tightening force of the collector $10.8 \cdot 10^{5} \mathrm{~N}$; the total pliability of the structure $\sum л=0.5 \cdot 10^{-8} \mathrm{~m} / \mathrm{N}$. The thermal deformations are expressed by:

$$
\begin{gathered}
\Delta \ell_{C u}=1056 \cdot \Delta \Theta \cdot 10^{-8}, \\
\Delta \ell_{F e}=1000 \cdot \Delta \Theta \cdot 10^{-8} .
\end{gathered}
$$

Dynamic molding refers to the operations of the technological process of collector production. In the dynamic formation of increasing the temperature of the copper circular arch and steel body is 
due to heat transfer from hot air to the outer surfaces of these structural elements. The total heat capacity of the steel body and the heating time is almost 2 times higher than that of copper, which results in a difference in the rates of temperature rise of these elements: at the initial section of the heating curve, the rate of increase of the copper temperature of the circular collector arch is 1.5 times higher than the speed increase of temperature of steel of the case; the copper temperature is set faster and the steel temperature continues to rise. Due to the different rate of rise in temperature and the time of setting the copper and steel collector temperature mechanical stresses during dynamic molding pass through a pronounced maximum, decreasing by the time of installation of the thermal process. The influence of centrifugal forces during the maximum of mechanical stresses leads to an increase of primary stresses of 1.76 times, which causes an excess of permissible stresses for cuffed miconite by $3 \%$ $[1-4]$. The following is an example of the calculation of the change in temperature and temperaturemechanical stresses in the elements of the collector locomotive DE1 during dynamic molding. According to [4] power loss on the working surface of the collector $P_{t r}+P_{e}=4040 \mathrm{~W}$. The effect of the armature winding is taken into account by increasing the power loss on the collector 1.3 times, the power loss on the surface of one plate $P_{1}=4040 \cdot 1,3 / 348=15,1 \mathrm{~W}$. Heat capacity of the plate

$$
C_{1}=c_{1} \cdot \mathrm{c}_{1} \cdot V_{1}=390 \cdot 8.9 \cdot 10^{3} \cdot 27.65 \cdot 10^{-6}=96 \mathrm{~W} \cdot \mathrm{s} /{ }^{\circ} \mathrm{C} \text {. }
$$

The heat capacity of the part of the body insulation included in the calculation sector is $C_{t_{2}}=C_{2} \cdot C_{2} \cdot V_{2}=920 \cdot 2.4 \cdot 10^{3} \cdot 3.525 \cdot 10^{-6}=7.8 \mathrm{~W} \cdot \mathrm{s} /{ }^{\circ} \mathrm{C}$. Heat capacity of the case included in the settlement sector

$$
C \tau_{3}=C_{3} \cdot \mathrm{c}_{3} \cdot V_{3}=480 \cdot 7.8 \cdot 10^{3} \cdot 50.82 \cdot 10^{-6}=190.3 \mathrm{~W} \cdot \mathrm{s} /{ }^{\circ} \mathrm{C} \text {. }
$$

Heat transfer coefficients $\alpha_{1}=234 \mathrm{~W} / \mathrm{m}^{2} \cdot{ }^{\circ} \mathrm{C}, \alpha_{3}=127 \mathrm{~W} / \mathrm{m}^{2} \cdot{ }^{\circ} \mathrm{C}$. The equivalent thickness of the case insulation $\delta_{2 e}=0.28 \cdot 10^{-2} \mathrm{~m}$. The calculation of the temperature-time dependencies of the collector elements is carried out in accordance with expressions (10) and (11). The heat capacity of the case insulation is added to the case $C_{2}=C \tau_{2}+C \tau_{3}=198.1 \mathrm{~W} \cdot \mathrm{s} /{ }^{\circ} \mathrm{C}$. The values of the coefficients in the expressions for $\Theta_{1}$ and $\Theta_{2}$ :

$$
\begin{gathered}
K_{11}=\alpha_{1} \cdot F_{1} / C_{1}+\lambda_{2} \cdot F_{2} / \delta_{2 e} \cdot C_{1}=0.00343 \mathrm{~W} \cdot \mathrm{s} /{ }^{\circ} \mathrm{C}, \\
K_{12}=\lambda_{2} \cdot F_{2} / \delta_{2 e} \cdot C_{1}=0.0002 \mathrm{~W} \cdot \mathrm{s} /{ }^{\circ} \mathrm{C}, \\
K_{p}=P_{1} / C_{1}=0.1573, K_{21}=\lambda_{2} \cdot F_{2} / \delta_{2 e} \cdot C_{2}=0.0000973, \\
K_{22}=\alpha_{3} \cdot F_{3} / C_{2}+\lambda_{2} \cdot F_{2} / \delta_{2 e} \cdot C_{2}=0.0009775 \mathrm{~W} \cdot \mathrm{s} /{ }^{\circ} \mathrm{C} ; \\
K_{1}=-0.00095, K_{2}=-0.0035, \Theta_{u 1}=46.8^{\circ} \mathrm{C}, \Theta_{i n i t}=-40{ }^{\circ} \mathrm{C} ; \\
K_{3}=-0.00095, K_{4}=-0.0035, \Theta_{u 1}=4.66{ }^{\circ} \mathrm{C} .
\end{gathered}
$$

In Fig. 3 shows the temperature-time dependencies of the collector elements for the specified mode. The analysis of these dependencies shows the following: at the initial section of the heating curves (up to 9 minutes from the start of the mode), the rate of increase of the copper arch circulating temperature is 5 times higher than the steel fasteners of the housing, then the rate of increase of the copper temperature drops to almost zero, and the steel of the fixing items stored; constant heating time of copper is about 9 minutes, steel fasteners - about 28 minutes. These dependencies are then used to calculate the collector temperature and mechanical stresses.

Fig. 4 shows the change of temperature-mechanical stresses of the collector elements. Analyzing the curves of changes in temperature mechanical stresses, it can be noted the following: temperature mechanical stresses in the elements of the collector pass through a pronounced maximum, decreasing in magnitude until the time of the steady-state mode, which is caused by the difference in the rate of change of excess temperatures of copper circular arches and steel mounting elements; the maximum of temperature mechanical stresses comes $(10-20)$ minutes after the start of the mode and is $10.3 \%$ of the value of the initial mechanical stresses in the fixed collector. The influence of the centrifugal forces of the corresponding accelerating speed during the maximum of temperature-mechanical stresses leads to an increase of initial stresses of 1.82 times, which causes an excess of permissible stresses for the cuffed miconite by $6 \%$. 


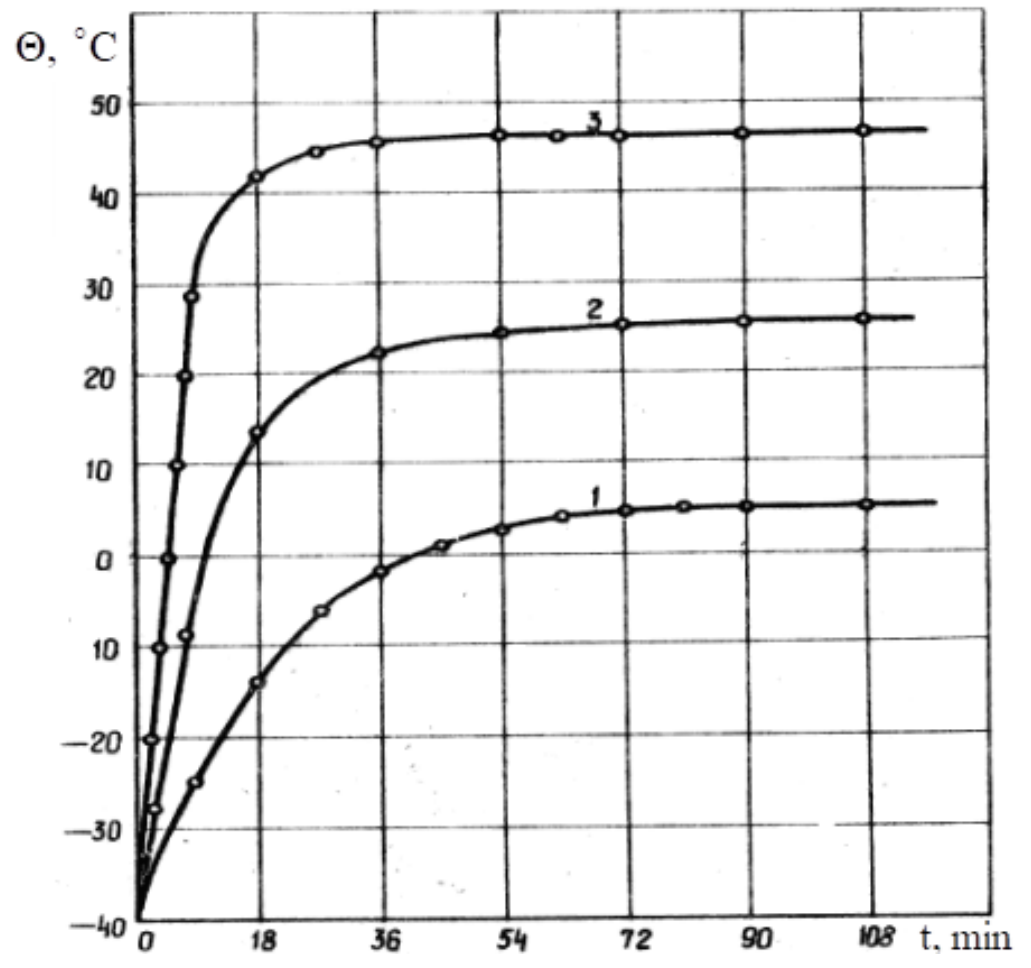

Fig. 3. Temperature-time dependence of the collector locomotive DE-1 elements in start-up mode with rated load
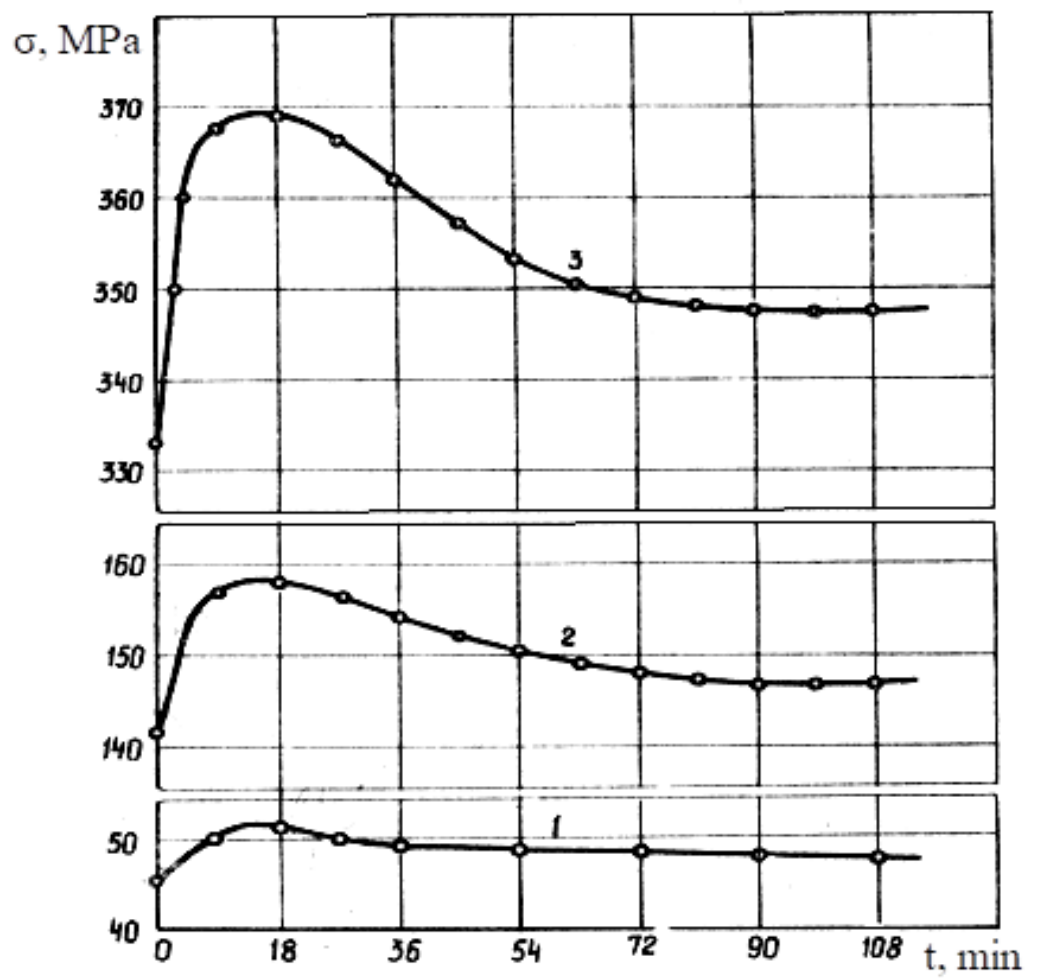

Fig. 4. Change of the electric locomotive collector DE-1 temperature voltages in start-up mode with rated load 
The temperature-time dependencies and changes in the temperature mechanical stresses of the collector elements for other modes are similar. Fig. 3 shows the temperature dependence of the following elements: case -1 , insulation -2 ; plate -3 . Fig. 4 shows the dependence of temperature stresses on time for the following elements: cuff -1 ; "swallow tail" plate -2 , clamping bolt -3 .

Thus, it is found that due to the different speeds of temperature rise and time of reaching constant temperatures of copper circular arch and steel fasteners of the structure, the temperature mechanical stresses in the elements of the TM collectors during unsteady mode pass through a pronounced maximum. The decrease in the magnitude of the temperature-mechanical stresses is caused by the prolonged thermal expansion of the structural steel elements, while the thermal expansion of the copper circular arch is almost stopped.

Algorithm for identification of temperature-mechanical stresses. Based on the above material, the following algorithm for identification of temperature-mechanical stresses may be proposed:

1. The time of transition is divided by the finite number of intervals at which copper and steel temperatures are fixed at the beginning and end of these intervals.

2. Calculation of non-constant temperature-mechanical efforts at successive time intervals of technological or operational processes requires the available data on the discrete temperature field of the collector parts, for which the method of numerical solving of differential equations of thermal conductivity by means of thermal circuits is used.

3. The difference of thermal deformations of copper and steel of the collector in the first time interval, the temperature effort and the coefficient of increase of the initial mechanical stresses from the temperature influence $K_{\Theta}$ is determined.

4. The multiplication of mechanical stresses at the beginning of technological or operational modes on $K_{\Theta}$ will give the amount of stress in the collector elements at the end of the first time period, which is the initial for the next period of time.

5. The identification process is repeated throughout the time interval.

\section{Conclusions}

The results of a theoretical study of the distribution of temperature-mechanical forces in TM collectors were conducted for the most dangerous difficult transient modes, which include: dynamic formation of the collector at a temperature of $+160 \mathrm{eC}$ at high speed; testing of $\mathrm{TM}$ made at high speed; start-up of TM under load in rated mode or at maximum load, limited collector insulation resistance class.

Chromel-Copel thermocouples were used to measure excess temperatures, mechanical forces in the elements of the collector were measured by means of strain gauges, to determine the regularities of the process of heat transfer from the collector surface to the cooling air, the method of steady heat flow and microclimate were applied. As a result of researches it is established that the maximum value of temperature-mechanical stresses can reach up to $35 \%$ from the value of initial mechanical stresses. The influence of centrifugal forces corresponding to the acceleration frequency of the collector during the maximum temperature-mechanical effort can lead to an increase in the initial mechanical stresses in the structural elements by $1.7-2.6$ times.

Most of the research results obtained for the manufacturing process of collectors main electric traction motors, but they can also be used to the technology of electric DC machines of other types.

\section{References}

[1] Meerzon Yu.M (2004). Analiz tehnicheskogo sostoyaniya tyagovyh dvigatelej [Analysis of the technical condition of traction engines] / Povyshenie resursa tyagovyh elektrodvigatelej Increasing the resource of traction motors: Proceedings of the scientific and technical conference of the Research Institute of Railway Transport. (Vols 1),.(pp.10-12). Moscow [in Russian]

[2] Klimchenkova N.V. (2001) Sovershenstvovanie tehnologii izgotovleniya kollektorov elektricheskih mashin na osnove analiza neustanovivshihsya parametrov[Improving the manufacturing 
technology of collectors of electrical machines based on an analysis of transient parameters]. Extended abstract of candidate's thesis. Donetsk:DonNTU [in Russian].

[3] V.T.Klimchenkov \& N.V.Klimchenkova (1995). Sposib dinamichnogo formuvannya kolektora [The method of dynamic formation of the collector] . Of. byul. «Promislova vlasnist» - Official Gazette "Industrial Property", 4, 21-26 [in Ukrainian]

[4] N.V.Klimchenkova \& V.T.Klimchenkov (1996).. Opredelenie parametrov temperaturnogo rezhima pri dinamicheskoj formovke kollektora s uchetom konstruktivnyh osobennostej [Determination of temperature parameters during dynamic formation of the collector, taking into account design features], Sb.nauch. statej. Donbasskoj gosud. mashinostr. akademii. - Proceedings of scientific articles of the Donbass State Engineering Academy (Vols.3), (s.496-499). Kramatorsk: DGMA [in Russian].

[5] Surovikov A.A., \& Klimchenkov V.T. (1982). Vliyanie relefa rabochej poverhnosti na raspredelenie nestacionarnyh temperatur i temperaturnyh napryazhenij v kollektore [The influence of the relief of the working surface on the distribution of unsteady temperatures and temperature stresses in the collector]. Elektromehanika - Electromechanics, 12, 1468-1470 [in Russian]

[6] Klimchenkova N.V (1996). Razrabotka modeli rascheta mehanicheskih nagruzok pri formovke kollektornogo kolca [Development of a model for calculating mechanical loads during molding of a collector elements]. Novye ekonomicheskie otnosheniya i kadrovoe obespechenie proizvodstva - New economic relations and staffing of production: proceedings of an interuniversity scientific conference (pp. 52-59). Kramatorsk: DGMA [in Russian]

\section{РОЗРОБКА МАТЕМАТИЧНОЇ МОДЕЛІ РОЗРАХУНКУ НЕСТАЛИХ ТЕМПЕРАТУРНО-МЕХАНІЧНИХ НАПРУЖЕНЬ У КОЛЕКТОРІ ТЯГОВОГО ЕЛЕКТРОДВИГУНА

\author{
Шеремет О.І., Клімченкова Н.В., Садовой О.В., Сохіна Ю.В.
}

\section{Реферат}

Близько 50\% всіх відмов тягових електродвигунів магістральних електровозів припадає на колектор, на якій впливають значні несталі температурно-механічні зусилля як у технологічних, так і в експлуатаційних режимах. В зв'язку з цим розробка методик розрахунку та ідентифікації несталих температурних полів і температурно-механічних напружень в елементах колекторів сучасних тягових електродвигунів набула в теперішній час особливої актуальності.

Мета роботи полягає в розробці методики розрахунку та ідентифікації температурних полів і температурно-механічних напружень у колекторах тягових електродвигунів при несталих режимах.

Відповідно до мети в роботі поставлені і вирішені наступні задачі: запропоновано послідовність розрахунку температурних механічних напружень та температур при несталих режимах; проведено теоретичні дослідження розподілу і зміни температур і температурно- механічних напружень в елементах колекторів тягових електродвигунів у несталих режимах; розроблено систему ідентифікації температурно-механічних напружень та надано рекомендації по їх зменшенню.

Результати теоретичного дослідження розподілу температурно-механічних зусиль у колекторах тягових електродвигунів проведені для найбільш небезпечних важких перехідних режимів, до яких відносять: динамічне формування колектору при температурі $+160^{\circ} \mathrm{C}$ на підвищеній частоті обертання; випробування виготовленого тягового електродвигуна при підвищеній частоті обертання; пуск тягового електродвигуна під навантаженням у номінальному режимі або при максимальному навантаженні, обмеженому класі нагрівостійкості ізоляції колектору. Для вимірювання перевищень температур використовувались хромель-копелеві термопари, механічні зусилля у елементах колектору вимірювались за допомогою тензорезісторів, для уточнення закономірностей процесу тепловіддачі з поверхні колектору до охолоджуючого 
повітря застосовано спосіб усталеного теплового потоку та мікрокліматичні датчики. У результаті досліджень встановлено, що максимальна величина температурно-механічних напружень може досягати до $35 \%$ від величини початкових механічних напружень. Вплив відцентрованих сил, які відповідають розгінній частоті обертання колектору під час максимуму температурномеханічних зусиль може призвести до збільшення початкових механічних напружень в елементах конструкції у 1,7-2,6 рази

Більшість результатів досліджень отримано для процесу виготовлення колекторів тягових електродвигунів магістральних електровозів, але вони можуть бути також використані до технології виготовлення електричних машин постійного струму інших типів.

\section{Література}

1. Меерзон Ю.М. Анализ технического состояния тяговых двигателей. Повышение ресурса тяговых электродвигателей: сб. трудов научно-техн. конференцци всерос. научно-исслед. железнодорожного транспорта. Москва, 2004. С. 10-12.

2. Климченкова Н.В. Совершенствование технологии изготовления коллекторов электрических машин на основе анализа неустановившихся параметров: автореф. дисс. на соиск. учен, степени канд. техн.наук: 05.09.01/ Донецкий нац. техн. университет. Донецк, 2001. 20 с.

3. Спосіб динамічного формування колектора: пат.71182 Україна: МПК7 Н02K 15/00,H01R 43/06 №20031110614; заявл. 01.12.93, опубл. 26.12.95, Бюл№4.21 c.

4. Климченкова Н.В., Климченков В.Т. Определение параметров температурного режима при динамической формовке коллектора с учетом конструктивных особенностей. Сборник научных статей Донбасской государственной машиностроительной академии. Краматорск,1996. №.3. С. 496-499.

5. Суровиков А.А., Климченков В.Т. Влияние рельефа рабочей поверхности на распределение нестационарных температур и температурных напряжений в коллекторе. Электромеханика.1982. № 12. С. 1468-1470.

6. Климченкова Н.В. Разработка модели расчета механических нагрузок при формовке коллекторного кольца. Новые экономические отношения и кадровое обеспечение производства Труды межвуз. науч.-техн. конф. Краматорск: ДГМА, 1996. С. 52-59. 